\title{
Simulation-Prediction Model of Soil Erosion in Lake Buyan
}

\author{
I Gede Aris Gunadi ${ }^{1, *}$ Dewi Oktofa Rachmawati ${ }^{1}$ Aldi Prayoga ${ }^{2}$ Muhammad \\ Fauzan $^{3}$
}

\author{
${ }^{1}$ Physics Education Study Program, Universitas Pendidikan Ganesha, Singaraja, Indonesia \\ ${ }^{2}$ Physiscs Education Program Study, Universitas Pendidikan Ganesha, Singaraja, Indonesia \\ ${ }^{3}$ Magister Computer Science Program Study, Universitas Pendidikan Ganesha, Singaraja, Indonesia \\ ${ }^{*}$ Corresponding author. Email: igedearisgunadi@undiksha.ac.id
}

\begin{abstract}
The existence of the lake is very important for the Balinese people, as a source of drinking water, as well as in the spiritual aspects of Hindu religion. One of the lakes on the island of Bali is Lake Buyan. Geographically, it is located in Pancasari village, Sukasada district, Buleleng, Bali. The Bali Provincial Public Works Department ' Data shows that in the last 15 years from 1999 to 2015, there is an increasing decrease in the area of the lake. In 1999 the area of the lake was recorded at $439 \mathrm{Ha}$ and shrunk in 2015 to $376 \mathrm{Ha}$. One of the factors that affect the area of the lake is the occurrence of soil erosion. In this study, a simulation model was developed to predict landslide/soil erosion conditions in Lake Buyan. This avalanche simulation model is based on the USLE (Universal Soil Loss Equation) formula. It is stated that erosion is influenced by soil erobility, rain erosivity, steepness of slopes, tillage, and soil conversion. Based on the developed simulation model, it is shown that the biggest influence that affects the landslide in Buyan Lake is rain erosivity. Rainfall predictions based on rainfall data for the last 10 years show that the rainfall is getting smaller. On the one hand, it will bring the advantage that the quantity of landslide erosion in the next few decades will be smaller. Based on the simulation model, predictions show that in 2020, 2030, 2040, and 2050 the amount of erosion is 116.5 tons, 74.23 tons, 18.62 tons, and 7.5 tons. On the other hand, this is very worrying because rain is the only source of water for Lake Buyan.
\end{abstract}

Keywords: Lake Erotion, USLE, Dynamic Simulation, Buyan Lake.

\section{INTRODUCTION}

The lake is one of the most important environmental aspects, which is a life support for the surrounding community. Bali has 4 large lakes, Lake Batur in Bangli Regency (1607, 5 Ha), Lake Bratan in Tabanan Regency (370 Ha), and Lake Buyan (360 Ha) and Tamblingan (110) in Buleleng Regency [1]. The four lakes are called 'Catur danu', which are the source of life for the Balinese people, the four lakes in their main function as producers of clean water sources for the Balinese people.

Respect for the lake in sad kertih is called danu kertih, which is an effort to maintain fresh water sources on land, such as springs, lakes, rivers, and others. The lake is a place where religious ceremonies are carried out in the form of rituals and are sacred. Like the mapekelem ceremony / salvation ceremony to the lake, and there are also people who carry out the melasti ceremony to the lake [2], [3].

Buyan lake, which is in the administrative village of Pancasari, Sukasada district, Buleleng district. Together with Tamblingan Lake, it is a source of drinking water for Buleleng Regency, and the city of Singaraja in general. Some people say the two lakes are twin lakes. Based on research conducted by the Udayana university team, [4], [5] For Lake Buyan in 1999, the area of the lake was about $439 \mathrm{Ha}$, ten years later it shrank by $5.9 \%$, the area was only $413.15 \mathrm{Ha}$, then in 2015 , only 376.6 Ha. from the period 2009 to 2015, the period of 6 years depreciation was $8.8 \%$.

There are many factors that cause lakes to decline in quality, both in terms of area, volume and water quality. In the data from the Public Works Agency [6], it is stated that several main problems of Lake Buyan include (1) 
unclear land boundaries of the lake so that it causes a lot of land use change, (2) high waste of agricultural and fishery activities, (3) very high sedimentation, (4) nonideal land elevation, (4) Illegal extraction of water.

Many factors that cause lakes to decline in quality, both in terms of area, volume and water quality. In the PU Department data [6], it is stated that several main problems of Lake Buyan include (1) unclear land boundaries of the lake so that it causes a lot of land use change, (2) high waste of agricultural and fishery activities, (3) very high sedimentation, (4) land elevation that is not ideal, (4) illegal extraction of water.

One of the dominant problems affecting the area and volume of the lake is the occurrence of landslides/erosion. The quality of landslides and soil erosion is influenced by natural conditions and excessive human activities [4], [7], [8], [9]. In this study, a simulation model is analyzed to predict landslide conditions in Buyan Lake in the future time.

\section{LiteratURE OF STUDY}

\subsection{The Environmental Conditions of Lake Buyan}

Buyan lake is one of the lakes mentioned as Tri danu in the article [2]. Geographically, Buyan Lake, Panca Sari Village, Sukasada District, Buleleng Regency. This lake is a source of drinking water and agriculture for the people of Central Bali, especially Buleleng Regency. Besides being a source of drinking water, Buyan Lake also provides benefits for fertile agricultural land (in the lakeside area), an extraordinary tourist charm. Realizing this, the Buleleng district government has actually made efforts to protect it, such as government regulation No. 36 of 2005, which regulates environmental and building layouts around Buyan Lake. Figure 1 shows the geographic location of Buyan Lake [10].

Buyan Lake is a caldera lake, which is a confined basin. The source of input water for Buyan Lake is rainwater. There are no rivers that enter as a source of water supply. Based on interviews with local communities, seepage occurred between three adjoining lakes, Lake Bratan, Buyan, Tambilangan.

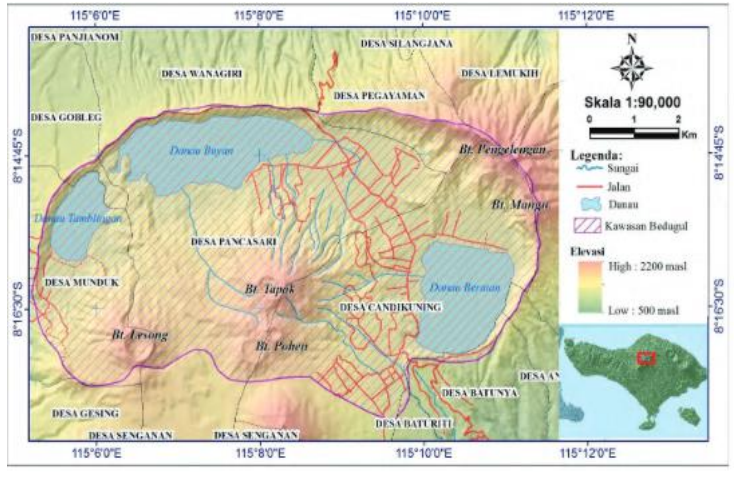

Figure 1. Map of Buyan Lake Bedugul Bali.

Some environmental conditions of Lake Buyan are shown in table 1 and Furthermore, the rainfall factor, the data is shown in table 2 by data $+/$ - the last 10 years 2010-2019, taken from the Baturiti/Pancasari weather post.

\subsection{Analysis of Erotion Land}

One approach used to measure erosion quality is to use the USLE formula (Universal Soil Loss Equation).

$$
A=R . K . L S . C . P
$$
A : Erotion of Soil (ton/Ha/tahun)
$\mathrm{R}$ : Erosivitas of Rain
K: Erobilitas of Soil
Ls : Land slope
C: Cultivation of Land
P: Conservation of Land

Table 1 . The Condition of Buyan Lake Environment Parameter

\begin{tabular}{|l|l|l|}
\hline Parameter & Value & Description \\
\hline Land slope & 3.1 & Land Slope 15-25\% \\
\hline $\begin{array}{l}\text { Conversion of } \\
\text { Land }\end{array}$ & 0.5 & $\begin{array}{l}\text { planting following the } \\
\text { contours of the land }\end{array}$ \\
\hline Land cultivation & 0.4 & $\begin{array}{l}\text { Potato farmland, } \\
\text { vegetables }\end{array}$ \\
\hline $\begin{array}{l}\text { Erobilitas of } \\
\text { Land }\end{array}$ & 0.21 & Meditern \\
\hline
\end{tabular}


Table 2. The Rainfall in Baturiti-Pancasari Bedugul

\begin{tabular}{|c|c|c|c|c|c|c|c|c|c|c|c|c|}
\hline Tahun & Januari & Februari & Maret & April & Mei & Juni & Juli & Agustus & September & Oktober & November & Desember \\
\hline 2010 & 645.4 & 458.4 & 373.9 & 701.4 & 302 & 119.5 & 108.4 & 130.7 & 279.9 & 509.4 & 368 & 573.6 \\
\hline 2011 & 558.2 & 405.7 & 165.5 & 445.7 & 285.1 & 13 & 22.9 & 6.2 & 49.7 & 121.6 & 342.1 & 338.3 \\
\hline 2012 & 565.3 & 332.7 & 444.1 & 362.9 & 156.3 & 17.3 & 90.6 & 10.9 & 6.1 & 136.4 & 273 & 401.7 \\
\hline 2013 & 294.5 & 550 & 333.7 & 328 & 220.8 & 207.8 & 141 & 20 & 13 & 18 & 344 & 491 \\
\hline 2014 & 388 & 134 & 94 & 198 & 60 & 4 & 141 & 22 & & 25 & 478 & 554 \\
\hline 2015 & 326 & 233 & 534 & 298 & 89 & 20 & 9 & 14 & 22 & & 127 & 351 \\
\hline 2016 & 315 & 640 & 312 & 260 & 410 & 130 & 284 & 153 & 248 & 337 & 484 & 506 \\
\hline 2017 & 513 & 396 & 402 & 305 & 147 & 106 & 106 & 51 & 47 & 270 & 469 & 447.9 \\
\hline 2018 & 644.9 & 616.1 & 446.6 & 163.6 & 43.7 & 104.9 & 93.4 & 177.8 & 29.6 & 20.5 & 425.4 & 297.6 \\
\hline 2019 & 563.7 & 261 & 469.9 & 446 & 70.1 & 128.2 & 11.9 & 8.4 & 9.4 & 1.4 & 275.9 & 310 \\
\hline
\end{tabular}

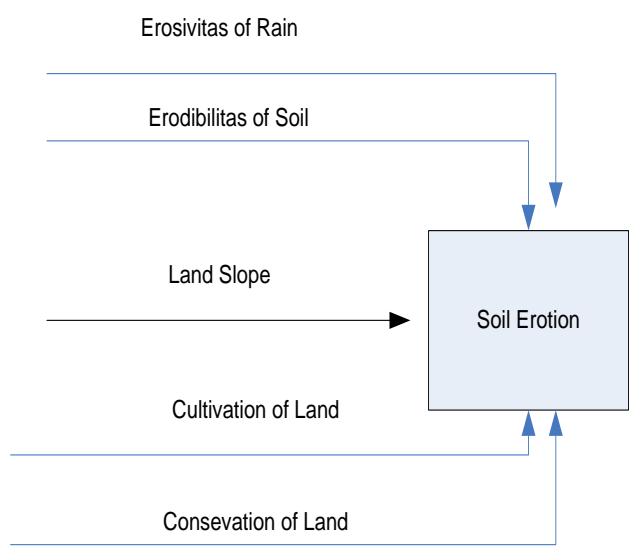

Figure 2. Causal Diagram of Model Erosion in Lake Buyan

\subsubsection{Erosivitas of Rain $(R)$}

Rain erosivity is determined by the equation proposed stated :

$$
\begin{aligned}
& R=10.8+4.15 . \mathrm{CH} \\
& R=10.8+4.15 . \mathrm{CH}
\end{aligned}
$$

$\mathrm{R}$ erosivity of rain , influenced by monthly rainfall $(\mathrm{CH})$ , expressed in units $(\mathrm{KJ} / \mathrm{Ha})$

\subsubsection{Erodibilitas of Soil $(K)$}

Soil erodibility is an index of soil sensitivity to natural factors, which cause erosion. Quantitatively, soil erodibility $(\mathrm{K})$ states the amount of soil lost on average per year per unit area.

\subsubsection{Slope of Land (Ls)}

LS is a combination of graded L (length of span) of the slope, and S (slope) of the slope. LS is one of the variables that determine the quality of erosion based on the USLE formula, which is stated in Equation 1. LS physically states the ratio of soil loss in a certain unit area, to the length (L) of the slope and the slope in that area.

\subsubsection{The Cultivation of Land $(C)$}

Soil tillage factors are associated with the types of plants that grow and are cultivated on the land, processing of crop residues, processing time, and soil fertility conditions. Several approaches are used to determine the tillage value $(\mathrm{C})$.

\subsubsection{The Conversation of Land $(P)$}

Practical land conversion is the amount of land that is lost if conservation is carried out on land, for example making terraces, plants in contours, and others.

\subsection{The Modeling of Dynamic Simulation}

One of the existing simulation model methods is the dynamic simulation model, which is a simulation model that involves time as an influential factor. In dynamic modeling, the goal is to describe quantitative changes in one or more certain variables. To be able to do this, the details of the system must be determined, the characteristics, the phenomena that occur in it, the elements that make up the system, the relationships and interrelationships between the constituent elements (system structure). All of them refer to the field of science related to the discussion of systems. For lake systems, there will be a lot of involvement in civil engineering, especially soil science for landslide analysis, biological or environmental sciences for discussing lake biomass, chemistry for analysis of lake inorganic organic matter content, fisheries science for lake fisheries activities. From the analysis of various disciplines, the structure of 
the system is finally obtained, which is then used as the basis for determining the causal model / structural model and finally being used as a behavior model (final simulation model).

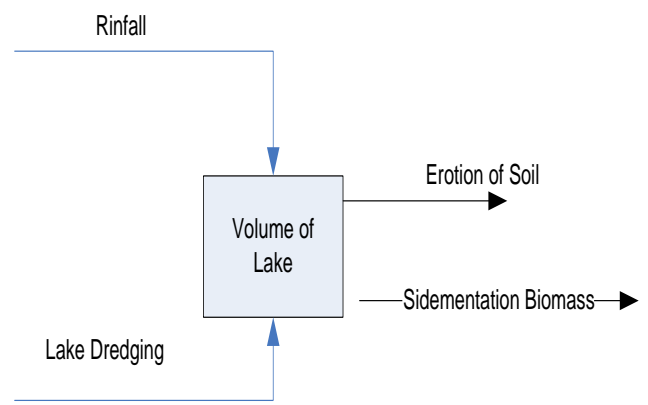

Figure.3. Causal Diagram Exsistention of Lake

The Buyan lake model based on a review of soil science and the occurrence of sedimentation, we state in this study expressed by the variable area $(\mathrm{Ha}) /$ water volume (million $\mathrm{m} 3$ ) of the lake, influenced by 3 factors. Rainfall as the main water source for the catchment area (catchment area) of Lake Buyan. There is also no river flowing from Buyan Lake, Buyan Lake is truly a perfectly confined basin. The possibility of seepage from rocks exists. The second factor that affects the area and volume of the lake is the landslide/soil erosion around the lake. The third factor is sidementation due to biomass decomposition.

\section{METHOD}

\subsection{Data Acquisition}

The data used are data issued by the official agency of the Public Works Agency (PU) of the province of Bali, Meteorological Agency data, as well as data from previous research results. The following is the data obtained related to the condition of Lake Buyan. These data are shown in Table 1 and Table 2. Furthermore, these data are used to develop a simulation model based on the USLE formula, Equation 1.

Some assumptions that are also taken in this research are: 1. Soil steepness/slope, expressed as a constant, whose value is fixed and is formed by natural influences. In this study, referring to the data of Lake Buyan, the steepness constant is 3.1 . This value shows $15-20 \%$, relatively steep conditions.

2. Soil erosion, real conditions currently show a value of 0.21 Mediterranean conditions, this value will change, if human activities are too excessive, but the process will take a very long time. In the simulation, a simulation model of the change value of $1 \%$ is made every year. So far, the author has not found the rate of change in soil erosion and what factors influence it.
3. Rain erosivity, expressed as a function affected by rainfall. The rainfall pattern used to predict rain for the next few decades is to use a rainfall pattern from 2010 to 2019. The pattern shows less rain from year to year in the future.

4. Tillage, in the initial condition study, was given a value of 0.4 , indicating a lot of potato fields, and other vegetables around the lake. This value will increase with population growth. In this condition, it is assumed that there is an additional $1 \%$ of land around the lake every year. This $1 \%$ value needs to be studied further.

5. Soil conversion factor, land conversion factor, currently in Buyan Lake, farmers are planting slopes according to hilly land contours, this condition is predicted / assumed to be getting worse, the change rate used for land conversion is $1 \%$. The conversion value of the land around Buyan Lake is 0.5 , there is no massive conservation yet.

\subsection{Model Simulation}

The simulation was developed using Powersim software. The data simulation is based on the data and assumptions stated above. For rainfall, the graph function is used. It is used to predict rainfall based on 2010-2019 rain data. Figure 4 shows a structural diagram of the landslide/erosion simulation model of Lake Buyan.

\section{RESULT AND DISCUSSION}

\subsection{Result}

The simulation results of landslide data for 2020 - 2050 are shown in Table 3, and the graphical simulation is in Figure 5 .

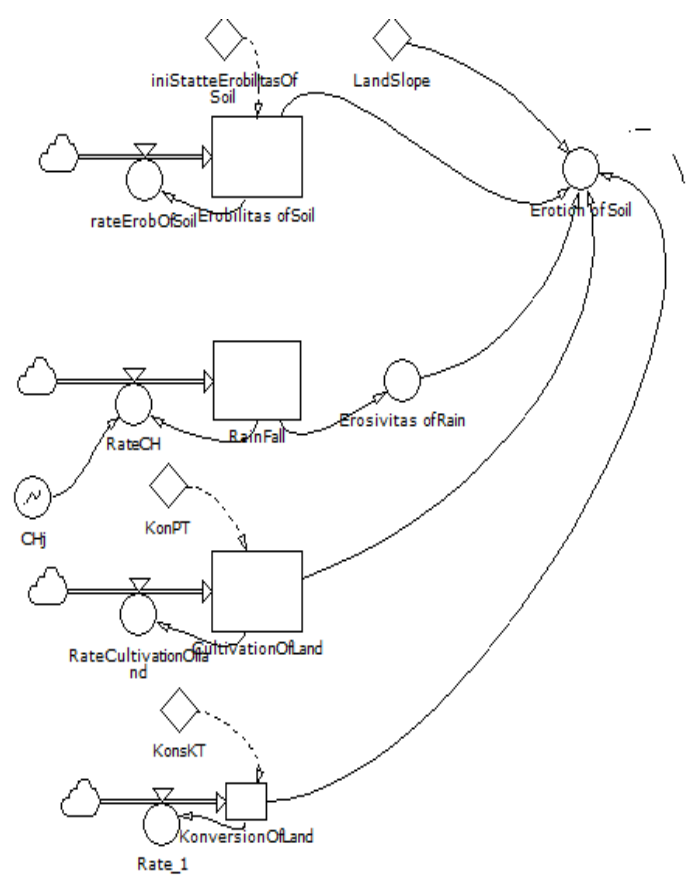

Figure 4. Model Simulation of Erotion Buyan Lake 
Table 3. Result Of Simulation Erotion Buyan Lake 2020- 2050

\begin{tabular}{|c|c|c|c|c|c|c|}
\hline year & Kecuraman & $\begin{array}{c}\text { Erobilitas } \\
\text { Tanah }\end{array}$ & $\begin{array}{c}\text { Erosivitas } \\
\text { Hujan }\end{array}$ & $\begin{array}{c}\text { Pengolahan } \\
\text { Tanah }\end{array}$ & $\begin{array}{l}\text { Konversi } \\
\text { Tanah }\end{array}$ & $\begin{array}{c}\text { Erosi } \\
\text { Lonsoran }\end{array}$ \\
\hline 2,020 & 3.10 & 0.21 & 894.75 & 0.40 & 0.50 & 116.50 \\
\hline 2,021 & 3.10 & 0.21 & 544.71 & 0.40 & 0.51 & 73.07 \\
\hline 2,022 & 3.10 & 0.21 & 551.65 & 0.41 & 0.51 & 76.24 \\
\hline 2,023 & 3.10 & 0.22 & 584.10 & 0.41 & 0.52 & 83.17 \\
\hline 2,024 & 3.10 & 0.22 & 453.96 & 0.42 & 0.52 & 66.60 \\
\hline 2,025 & 3.10 & 0.22 & 437.56 & 0.42 & 0.53 & 66.14 \\
\hline 2,026 & 3.10 & 0.22 & 799.46 & 0.42 & 0.53 & 124.51 \\
\hline 2,027 & 3.10 & 0.23 & 641.72 & 0.43 & 0.54 & 102.97 \\
\hline 2,028 & 3.10 & 0.23 & 601.98 & 0.43 & 0.54 & 99.52 \\
\hline 2,029 & 3.10 & 0.23 & 504.43 & 0.44 & 0.55 & 85.92 \\
\hline 2,030 & 3.10 & 0.23 & 422.98 & 0.44 & 0.55 & 74.23 \\
\hline 2,031 & 3.10 & 0.23 & 354.97 & 0.45 & 0.56 & 64.18 \\
\hline 2,032 & 3.10 & 0.24 & 298.18 & 0.45 & 0.56 & 55.55 \\
\hline 2,033 & 3.10 & 0.24 & 250.77 & 0.46 & 0.57 & 48.13 \\
\hline 2,034 & 3.10 & 0.24 & 211.17 & 0.46 & 0.57 & 41.76 \\
\hline 2,035 & 3.10 & 0.24 & 178.11 & 0.46 & 0.58 & 36.29 \\
\hline 2,036 & 3.10 & 0.25 & 150.50 & 0.47 & 0.59 & 31.59 \\
\hline 2,037 & 3.10 & 0.25 & 127.45 & 0.47 & 0.59 & 27.56 \\
\hline 2,038 & 3.10 & 0.25 & 108.21 & 0.48 & 0.60 & 24.11 \\
\hline 2,039 & 3.10 & 0.25 & 92.13 & 0.48 & 0.60 & 21.15 \\
\hline 2,040 & 3.10 & 0.26 & 78.71 & 0.49 & 0.61 & 18.62 \\
\hline 2,041 & 3.10 & 0.26 & 67.51 & 0.49 & 0.62 & 16.45 \\
\hline 2,042 & 3.10 & 0.26 & 58.15 & 0.50 & 0.62 & 14.60 \\
\hline 2,043 & 3.10 & 0.26 & 50.34 & 0.50 & 0.63 & 13.02 \\
\hline 2,044 & 3.10 & 0.27 & 43.81 & 0.51 & 0.63 & 11.68 \\
\hline 2,045 & 3.10 & 0.27 & 38.37 & 0.51 & 0.64 & 10.54 \\
\hline 2,046 & 3.10 & 0.27 & 33.82 & 0.52 & 0.65 & 9.57 \\
\hline 2,047 & 3.10 & 0.27 & 30.02 & 0.52 & 0.65 & 8.75 \\
\hline 2,048 & 3.10 & 0.28 & 26.85 & 0.53 & 0.66 & 8.06 \\
\hline 2,049 & 3.10 & 0.28 & 24.20 & 0.53 & 0.67 & 7.49 \\
\hline 2,050 & 3.10 & 0.28 & 21.99 & 0.54 & 0.67 & 7.01 \\
\hline
\end{tabular}

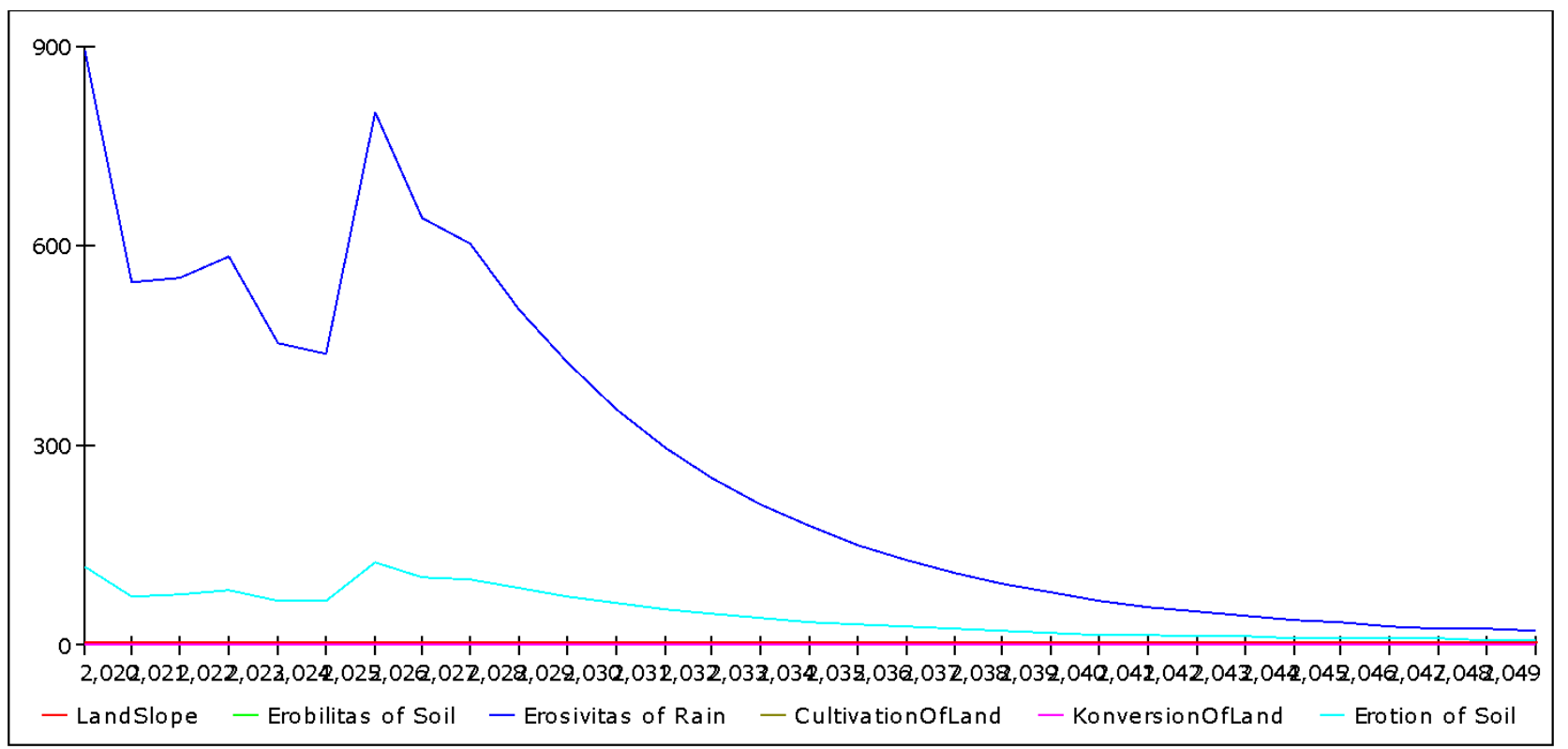

Figure 5. Pattern Simulation Of Erotion 2020-2050 


\subsection{Discussion}

The simulation results are obtained with several assumptions taken, which can be a concern as a limitation in the analysis of the results shown above.

(a) Rainfall pattern is assumed to follow the pattern of rainfall in the last ten years. The simulation results show that rainfall is getting smaller and smaller in the lake area. On the one hand, this will be advantageous, because landslide erosion is predominantly influenced by rainfall, rainfall will carry or wash away soil material. But of course the predicted minimal rainfall is very worrying. One source of lake water is from rain.

(b) The pattern of growth rates for several variables, because the data from the Public Works Service which oversees the supervision of lakes and rivers, the Environmental Service, as well as from various previous research publications, have not found this variable rate. The variable rate is mainly the rate related to environmental changes, such as the rate of change in soil conversion, the rate of tillage, the rate of soil erosion in this study using the assumption of $1 \%$. These variables will logically experience growth, along with population growth, and increased population activity, and improve the economy in the environment around the lake. The social relationship of population to the variable rate is real and logical, but very complex, and there is no theory that explains it.

\section{CONClusion}

Some conclusions that can be drawn from this research are:

1. Based on the simulation model made, it can be shown that the existence or sustainability of Buyan Lake is strongly influenced by the rainfall that occurs. Buyan lake is a caldera lake, whose water source is obtained from rain, and there are no other water sources.

2. Based on the 2010-2019 rainfall pattern, the rainfall pattern is very worrying, the peak area of the catchment area (catchment area) in the next 30 years is predicted to be a dry area, and this will greatly affect the condition of the lake.

3. Landslides in the next few years will not be a problem, because the main factor, rain erosivity shows a significant decrease.

4. Based on these conditions, the condition of the lake needs serious attention, although landslides are decreasing, the volume of lake water will certainly shrink.

\section{ACKNOWLEDGMENTS}

We would like to thank Ganesha University of Education, which has supported this research through DIPA research funding

\section{REFERENCES}

[1] BPS Bali, "Ketinggian Ibu Kota Kabupaten, Nama dan Luas Danau di Provinsi Bali,” 2018. https://bali.bps.go.id/statictable/2018/04/10/48/k etinggian-ibu-kota-kabupaten-nama-dan-luasdanau-di-provinsi-bali.html.

[2] I. K. Wiana, "Sad Kertih': Sastra Agama, Filosofi, dan Aktualisasinya," J. Bali Membangun Bali, vol. 1, no. 3, pp. 169-180, 2018, doi: 10.51172/jbmb.v1i3.29.

[3] I. B. G. Candrawan, "Kosmologis Masyarakat Hindu Di Kawasan Tri Danu Dalam Pelestarian Lingkungan Hidup," Dharmasmrti J. Ilmu Agama dan Kebud., vol. 14, no. 27, pp. 23-35, 2015, doi: 10.32795/ds.v14i27.44.

[4] I. M. Nada, I. B. Suryatmaja, and I. G. N. A. Wiswasta, "Model Penanggulangan Sedimentasi Danau Berbasis Masyarakat Di Pulau Bali," Bumi Lestari J. Environ., vol. 17, no. 2, p. 100, 2017, doi: 10.24843/blje.2017.v17.i02.p02.

[5] D. L. H. P. Bali, "Buku Data Status Lingkungan Hidup Daerah Provinsi Bali Pemerintah Provinsi Bali Tahun 2010," 2010.

[6] Dinas Pekerjaan Umun (PU) Prov Bali, Profil danau di ws bali-penida. 2020.

[7] T. Endarini, "Dampak Kegiatan Masyarakat Pada Kualitas Air Danau Buyan, Kabupaten Buleleng , Bali = Impact of Community Activities on The Water Quality of Buyan Lake , Buleleng Regency , Bali,” 2003.

[8] G. M. K. Kadek Diana Harmayani and I. B. D Permana, "Konfrensi Nasional Teknik Sipil 9," 2014.

[9] M. W. Syah and T. Hariyanto, "Klasifikasi Kemiringan Lereng Dengan Menggunakan Pengembangan Sistem Informasi Geografis Sebagai Evaluasi Kesesuaian Landasan Pemukiman Berdasarkan Undang-Undang Tata Ruang Dan Metode Fuzzy (Studi Kasus: Donggala, Sulawesi Tengah)," J. Tek. Pomits, vol. 10, no. 10, pp. 1-6, 2013.

[10] Sutomo, R. Iryadi, and W. Sujarwo, Bedugul Dari Angkasa. 2019. 